\title{
HEPATIC COMA
}

\author{
By J. M. Walshe, M.A., M.R.C.P. \\ From the Medical Unit, University College Hospital Medical School
}

\section{The Clinical Syndrome}

Hepatic coma has been defined by Adams and 'Foley (1953) as ' a disorder of consciousness, i.e. a lack of awareness of stimuli and failure to respond accompanied by a generalized disorder of movement. The derangement of consciousness presents first as a mental confusion, with either increased or decreased psychomotor activity, followed by stupor and coma.' Strictly it should be added that these symptoms and signs are associated with and are secondary either to a failure of liver function or to a gross disturbance of the portal and hepatic circulation.

While hepatic coma should not be diagnosed merely by a process of exclusion there is at present no single physical sign or biochemical determination which is by itself diagnostic of the condition. Clinically hepatic coma falls into three broad groups, first the coma of acute hepatic necrosis, second the coma of chronic hepatitis with slowly progressive parenchymal cell failure and third coma, associated with an apparently inactive and well compensated cirrhosis, which has been precipitated by some abnormal biochemical load upon the liver. It is in their mode of onset rather than in their fully developed form that these differ., Acute hepatic necrosis may result from either virus hepatitis or from poisoning by such chemicals as the halogenated hydrocarbons, phosphorus, the toxin of the poisonous fungus amanita phalloides, and an increasing number of drugs in current use. It may develop at any time during the course of an attack of hepatitis, and is most commonly found in young women of the child-bearing age. Coincident with or preceding the development of mental symptoms there is usually a deterioration in the clinical condition, nausea becomes intense and vomiting troublesome; foetor hepatis is also to be expected. In the older age groups drowsiness and nightmares are apt to be the first sign of nervous system involvement, but in children and young adults excitement or frank mania may develop. This phase of excitability may last a few hours or several days and if associated with fits of screaming may present a real problem in sedation. Another sign of impending coma is failure to recognise near relatives or confusion as to time or place. Physical examination of the nervous system at this stage shows that the tendon jerks are increased, ankle clonus is often present and, sometimes, extensor plantar responses. Flapping tremor of the hands on sustained posture is also a valuable sign of impending coma and should be carefully and repeatedly sought when this is suspected. Once fully developed the coma of acute hepatic necrosis differs little if at all from other forms of hepatic coma with the important exception that it has a very much higher mortality. After a few days the increased muscle tone and tendon jerks give place to flaccidity, the temperature and pulse begin to rise and death is then imminent.

In chronic hepatitis, of the type described by Alsted (1947) in menopausal women, leading to active progressive fibrosis and in patients with alcoholic cirrhosis there is seldom the phase of excitement seen in acute hepatic necrosis. The onset of coma is much more insidious, the patient becomes increasingly lethargic and drowsy and readily falls asleep, but can at first be easily roused. As the illness progresses some mild confusion is to be expected. Finally a stage is reached, after days or perhaps weeks, in which drowsiness has become light coma, the patient will respond readily to painful stimuli and there may be frequent grimacing and pursing or sucking movements of the lips together with a flapping tremor, increased tendon jerks and ankle clonus. In the alcoholic, however, the tendon jerks are depressed or absent as peripheral neuritis usually precedes the development of hepatic failure by months or years. Besides signs in the nervous system the classical signs of severe chronic liver disease are to be expected, though jaundice is not necessarily always present and foetor hepatis is less often found than in acute hepatic necrosis. After a few days in light coma the patient may return to a state of confusion and even normality and then relapse again into coma. This fluctuating course may last for weeks or months, but progressive mental deterioration can be detected between the episodes of coma, and 
some of the physical signs, such as the flapping tremor of the hands, may never disappear completely. Eventually deep coma will develop and once the increased tendon jerks have given way to flaccidity no recovery can be expected.

In patients with apparently well compensated liver disease the reserve of function may be too small to handle any extra demands which it may be called upon to meet. Of these the commonest are intercurrent infection, to which patients with liver damage are peculiarly susceptible, the injudicious use of hypnotics, paracentesis, a high protein diet, the administration of ammonium chloride or ion exchange resins in the ammonium phase (Gabuzda, et al., 1952) and finally haemorrhage from the upper gastrointestinal tract. Patients in whom large portal-systemic collateral veins are present, whether spontaneously developed or resulting from the surgical production of an Eck fistula, seem to be particularly susceptible to the toxic action of a high protein diet and methionine, or to the presence of blood in the gut. Fully developed coma in these patients is identical with that already described, but the stage of precoma may be very prolonged and readily misdiagnosed, particularly in the Eck fistula type of patient in whom symptoms only develop when protein tolerance is exceeded. Tremor of a Parkinsonian type, slurring of speech and confusion are the typical signs and may be remarkably chronic. Symptoms lasting as long as two years have been described (Wilson and McAlpine, 1953; Sherlock, et al., I954). It is probable that a number of these patients may find their way into mental hospitals because of their confused mental state and often inappropriate behaviour. Patients with portacaval shunts are peculiarly liable to this syndrome and it may prove to be one of the principal contraindications to the operation.

\section{The Nature of the Biochemical Lesion}

It is not possible in a short article such as this to review fully the recent literature on the pathogenesis of hepatic coma. It is now, however, clearly established that the histological changes which are found in the brains of patients dying of hepatic failure, characteristic though they are (Adams and Foley, I953), cannot account for the clinical syndrome and that the underlying disorder must be due to a biochemical and not to a structural lesion. Further it has been established that the onset of coma is associated almost invariably with a disturbance of nitrogen metabolism which leads to a rise in the concentration of the blood ammonia (Van Caulaert and Deviller, 1932; Schwartz, et al., 1953; McDermott and Adams, 1954, and many other workers). There is also some evidence that occasionally an abnor mality of sulphur metabolism may be implicatef in the genesis of hepatic coma (Walshe, 195 I Challenger and Walshe, I955; Phear, et al., 1956)

In interpreting work on the correlation between: an elevated blood ammonia and the developments of coma it should be realised that the methods used for the estimation of blood ammonia will, in facto determine all diffusible alkali that may be present in blood or be liberated from shed blood under the conditions of the experiment; that is the additiono of whole blood to strong alkali either in the Conway micro-diffusion dish or the Seligson $P$ micro-diffusion bottle.

Moreover, results obtained by workers using these two techniques show certain importan discrepancies. For instance White, et al. (1955) confirmed Conway's original observation that, after shedding, the ammonia concentration of blood rises with time and by extrapolation back N to zero time found no ammonia present in normals blood. Bessman (1956), using the Seligson technique, reported that the concentration of ammonia in blood does not alter significantly withtime after shedding and he also found a higher normal blood ammonia than has been reported byô workers using the Conway technique. The obvious conclusion to be drawn from these observations is that these two methods a wec measuring not blood ammonia but some unstabe compound present in blood which is broken dowino at a different rate under different experimental s conditions to liberate diffusible alkali. Whether the raised blood ' ammonia' reported in hepatico disease is due to an increase in this unstable $\mathbb{\mathbb { Q }}$ compound or whether it is due to the failure $a \overrightarrow{\vec{F}}$ stabilizing system normally presents remains to be 3 seen. An alternative explanation favoured by? Bessman is that the Conway method gives a false. low result as part of the free ammonia is lost $; \overline{0}$ either being used in carbamyl phosphate synthesis? or by diffusion into cells. However, as both' techniques under discussion use saturated potas sium carbonate to liberate ammonia this explanation is hardly adequate. Finally the recent work of Bessman, et al. (1954 and 1955), and of Webstes (I955), has shown that the 'ammonia' con $\rightarrow$ centration varies greatly depending upon the site from which blood is drawn and peripheral veiñ ' ammonia' may not truly reflect the concentra-' tion of ' ammonia ' reaching the brain, an observa-O tion which necessarily throws doubt on thew validity of all earlier work on the correlation of neurological signs with blood ' ammonia' levelso

Despite these theoretical difficulties there is no doubt that, in patients with hepatic disease,,+ coma can be precipitated by the oral administra- $T$ tion of ammonium salts (Van Caulaert, et al., $\frac{\text { के }}{\mathbb{Q}}$ 
1933; Phillips, et al., 1952; White, et al., 1955), by ion exchange resins in the ammonium phase (Gabuzda, et al., 1952) or by high protein diets (Schwartz, et al., 1954), and in all cases in which the syndrome is so induced the blood ' ammonia' is elevated. Similarly in dogs with Eck fistulae a neurological syndrome can be produced by the administration of ammonium salts or by forced meat feeding and the onset of symptoms is associated with a raised ' ammonia ' concentration in the blood (Riddell, et al., 1954). In dogs, as in man, the normal blood 'ammonia' level is around $50 \mu \mathrm{g}$./ $100 \mathrm{ml}$., but symptoms of meat intoxication do not develop in the dog until the blood ' ammonia' is over $700 \mu \mathrm{g}$./ $100 \mathrm{ml}$., whereas in man the syndrome of hepatic coma is usually associated with a blood 'ammonia' of between 150 and $250 \mu \mathrm{g} . / 100 \mathrm{ml}$., although higher levels have been reported. Clearly it is dangerous to argue from the experimental animal to man. In sheep and cattle the normal jugular vein ammonia may be as high as 200 to $300 \mu \mathrm{g}$./100 ml. (Repp, et al., I 955 ; Head and Rook, I955) and the normal blood sugar is 30 to $40 \mathrm{mg}$./100 ml. (Reid, 1950). In other words these biochemical findings, if applied to man, would indicate that the patient was in the terminal stage of hepatic coma. Perhaps they go some way to explain the intellectual poverty of the sheep although it seems improbable that a glucose and glutamate infusion would significantly improve its performance. In the sheep too a syndrome of urea toxicity has been described and generally attributed to the liberation of ammonia by intestinal fermentation. The picture of urea toxicity in sheep is not in fact reproduced by intravenous ammonium salts, but is closely mimicked by the oral or intravenous administration of ammonium carbamate and Hale and King (1955) have further shown that ideal conditions exist for the formation of this compound in the abomasum of the ruminating sheep. This must seriously raise the question as to the rôle of this compound in the genesis of hepatic coma in man when it is precipitated by oral urea or a high protein load in the gut.

The difference between man and the experimental animal was further emphasized by the finding of Benitez, et al. (1954), of a normal cerebral ammonia concentration in dogs of $360 \mu \mathrm{g}$./ $/ 00 \mathrm{~g}$., and that infusions of ammonium salts did not produce convulsions until the ammonia concentration approached 5,000 $\mu \mathrm{g} . / 100 \mathrm{~g}$. It is difficult to interpret the reported levels for resting brain ammonia concentration as this varies greatly with the method used for killing the animal (Richter and Dawson, r948) and these authors showed that brain can rapidly liberate up to $\mathrm{I}, 000 \mu \mathrm{g}$. ammonia per $100 \mathrm{~g}$. on stimulation. Weil Malherbe (1955) has also pointed out that 'brain tissue is capable of forming considerable amounts of ammonia in vivo and in vitro,' and that the quantity of ammonia so formed rises sharply after convulsions whether produced chemically or electrically. At present the question remains unanswered whether the ammonia so liberated is the cause or the effect of the convulsion. In vitro inhibition of brain metabolism is only produced by ammonia at concentrations very much higher than those reported in hepatic coma (Edson, 1935; Findlay, et al., 1954). At high dilutions the ammonium ion closely mimics potassium (Gore and McIlwain, r952; Mann, et al., r939), and under these conditions will do so at concentrations which have occasionally been reported in man, that is around $\mathrm{I}, 000 \mu \mathrm{g} . / 100 \mathrm{ml}$.

Bessman has attributed the toxic action of ammonia to its ability to remove ketoglutarate from the Krebs cycle (Bessman and Bessman, I955), but this theory does not allow for the replacement of $\mathrm{C}_{4}$ acids from glutamic acid by transamination (Weil Malherbe, 1952). Glutamate is present in the brain in high concentration (Weil Malherbe, I950), is readily taken up by the brain against the concentration gradient (Stern, et al., I949) and can support respiration and response to stimulation of the human cerebral cortex when present as the only substrate (McIlwain, I953). In the present state of knowledge it is difficult to attribute the symptoms of hepatic coma in man to ammonia at the concentrations reported unless some other factor is postulated such as a break down in the ammonia binding mechanism of the brain of patients with severe liver disease (Walshe, r955).

Certainly it is not possible to mimic the syndrome of hepatic coma in man by giving ammonium salts unless severe liver damage is also present. Concentrations of blood 'ammonia' as high as $1.8 \mathrm{mg} . \%$ were reached in some patients of Seegmiller, et al. (1954), without the development of abnormal symptoms and in schizophrenics ammonium chloride infusions have been used to produce convulsions (Ajmone-Marsan, et al., I949), an extremely uncommon complication of hepatic coma. Experimental studies on rats, using the standard Warburg technique, have lent support to the theory that, when liver damage is present, the brain handles ammonia in a manner different from that of the normal animal (Walshe, 1956).

If the rôle of ammonia in the genesis of hepatic coma is not yet satisfactorily defined there is no other theory that comes so near to conforming to the observed facts. But brief mention must be made of other clues which may eventually help 
towards the solution of the problem. The administration of methionine to patients with severe hepatic disease can precipitate coma (Watson, 1949; Phaer, et. al., 1955 and 1956). ' Methionine sulphoxide, a glutamic acid antimetabolite which might interfere with ammonia binding in the brain, has been reported in the plasma and spinal fluid of patients in hepatic coma (Walshe, 195 I and 1953). Methyl mercaptan has been isolated from the urine of a patient dying of acute hepatic necrosis by Walshe and Challenger (1955) who pointed out that this was probably derived from methionine by hydrolytic or reductive fission of the carbon sulphur bond, an alternative metabolic pathway which might be used when the normal process of transmethylation is interrupted. Although little is known of the pharmacology of methyl mercaptan it is potentially a toxic compound. Indole metabolism has not been closely studied in patients with liver disease, but either a failure of the function of detoxification in the liver or the development of extensive portal collateral veins might result in a raised concentration of these compounds reaching the arterial blood. In extremely high dilutions certain indoles can profoundly disturb consciousness; adrenochrome, lysergic acid diethylamide and serotonin (5 hydroxy tryptamine) are all indolic compounds with an hallucinogenic action (Marrazzi and Ross Hart, 1955). Using the standard Warburg technique it can be shown that a number of simple derivatives of indole seriously disturb brain slice metabolism with a resultant marked increase in ammonia production at concentrations similar to those at which the known hallucinogens are active in vitro (Walshe, 1956). The indoles are certainly formed in the gut by bacterial action and it is not improbable that a large gastrointestinal haemorrhage or high protein feeding would result in increased production at the same time as the ammonia formation increases.

Severe electrolyte disturbances will also result in the onset of coma in patients with liver disease, though whether this is truly hepatic coma is doubtful; this is, perhaps, a question of terminology into which I do not propose at present to enter.

\section{Treatment}

Without a certain understanding of the underlying metabolic lesion giving rise to hepatic coma it is difficult to be dogmatic about the best form of treatment. There are, however, certain general principles. which are applicable to the treatment of all comatose patients and these should not be neglected in favour of attempts directly to influence the specific biochemical lesion of hepatic coma.
These general principles include maintenance of the fluid and electrolyte balance, an adequat supply of calories, prevention of infection and, as far as possible; assurance of an adequate supply ob oxygen to the brain. I do not propose to deal indetail with all these points but only to refe briefly to the more controversial aspects.

Electrolyte disturbances are common in patients? with severe liver damage. Fluid retention is often associated with a low serum sodium (Hilton 1952; Schwartz, et al., 1953), and occasionally? correction of deficiencies of either sodium of potassium may be followed by a return of con $\overrightarrow{0}$ sciousness (Artman and Wise, 1953); certainly serious deficiencies of either should be replaced when possible, though when oliguria is present extreme care should be taken not to give excess? potassium. Salt poor human albumin has beet advocated for the treatment of ascites when the plasma electrolytes are not greatly disturbed (Post, et al., I95I) but, as a powerful plasma expander, this is liable to precipitate dangerous haemorrhage if portal hypertension is presento Under these circumstances the use of sodium? restriction and mercurial diuretics are probably safer and more likely to succeed (Hilton, 1952) ammonium chloride and diamox are, howeverg dangerous and should not be given. When severe sodium depletion is associated with fluid retention much benefit is sometimes obtained by giving $300 \mathrm{ml}$. of $5 \% \mathrm{NaCl}$ and following this wh restriction of fluids by mouth.

The patient in coma will not need more than I,, 00 calories daily unless fever is present. Thesen can be supplied easily as $25 \%$ glucose solution without overloading the circulation with fluid. To을 avoid venous thrombosis this should be given bye polythene catheter direct into the vena cava or into a peripheral vein after addition of smale doses of hydrocortisone to the infusion mixture (Polak, 1956).

Prevention of infection will require the use not only of an antibiotic but also expert nursing care. and the avoidance of unnecessary instrumentationg of the urinary tract. As a covering antibiotic penicillin has many advantages and can be replaced later by one of the tetracyclines if require to eradicate some specific organism. In patients who appear likely to be unconscious for any length: of time a tracheotomy reduces the risk of inhalation of gastric contents especially if it is decided to feed them by stomach tube. Blood loss from the gastrointestinal tract should be carefully sought and anaemia corrected either by whole blood of packed cell transfusions. Haemorrhage front oesophageal varices is a major emergency iro patients with severe liver disease and is a frequent precipitating cause of coma. 
Treatment of the specific biochemical lesion of hepatic coma has been concerned mainly with attempts to correct the disordered nitrogen metabolism and to promote glucose utilization. To achieve these results the following means have been used: protein withdrawal or the administration of glutamic acid, aureomycin, cortisone or lipoic acid (6.8 dithiol octanoic acid).

The evidence for suspecting ammonia as a causative agent in the onset of hepatic coma has already been considered; reduction of the protein content of the diet will reduce ammonia production by bacterial action in the gut. This undoubtedly leads to a marked improvement in many cases of hepatic coma, particularly those in which there are large portal collateral veins (McDermott and Adams, 1954; Schwartz, et al., 1954; Sherlock, et al., 1954). During protein withdrawal calories can be supplied as glucose only; this is well tolerated for one or two weeks. If necessary protein can be given as small pool plasma, two bottles of which contain approximately $45 \mathrm{~g}$. As consciousness returns tube feeding becomes safer and the problem less difficult but protein should be restored only gradually to the diet. Aureomycin has been recommended in the treatment of hepatic coma and Farquhar, et al. (1950), believed that the improvement they observed was due to a reduction in bacterial fermentation in the gut, and Phear, et al. (1956), have shown that it will reduce or abolish the symptoms of methionine toxicity. Other workers have been less successful with this form of treatment (Shank, r952; Patek, 1954), and it has been pointed out that large doses of aureomycin might actually in themselves be hepatotoxic (Lepper, et al., 195I ; Rutenberg and Pinkes, 1952).

Glutamic acid plays a central part in the ammonia binding mechanism of the brain (Weil Malherbe, 1950). Intravenous sodium glutamate has been recommended in the treatment of hepatic coma (Walshe, I953), and there is now much evidence that its use is indeed followed by a fall in the blood' 'ammonia' concentration (Riddell and McDermott, 1954; Sherlock, et al., 1954; McDermott, et al., 1955; Bessman and Bradley, 1955; Webster and Davidson, 1956); in some cases this fall in the blood ' ammonia' level has been followed by a return of consciousness. Originally Walshe (I953) gave $23 \mathrm{~g}$. of monosodium glutamate daily by vein but later suggested giving a mixture of the sodium and potassium salts, in a ratio of 3 to $I$, to avoid the hypokalaemia which may otherwise develop, particularly in view of the larger doses of glutamate which were being employed (Walshe, r955). Very large doses have been given by Webster and Davidson (1956) but the risk of overloading with sodium is great.
Cortisone, in doses of 500 to $1,000 \mathrm{mg}$. a day, may occasionally be of value in patients with acute hepatic necrosis, a condition which otherwise has such a high mortality (Ducci and Katz, I952; Evans, et al., 1953). In chronic liver disease the results have been rather disappointing (Sklar and Young, r955) and there is apparently a risk of portal vein thrombosis in patients with portal hypertension (Eisenmenger, et al., 1952).

Lipoic acid is necessary for pyruvate to enter the Krebs cycle; disturbances of keto acid metabolism have been reported in hepatic coma (Carafango, et al., 1953), and this suggested that the thiol groups in lipoic acid might be blocked or that this co-enzyme factor itself might be deficient. Recently Lisan, et al. (1955), have reported good results following the use of this compound. The small number of cases I have seen treated with lipoic acid have been less successful.

Vitamins have no curative rôle in hepatic coma but vitamin $\mathrm{K}$ should be given to lessen the risk of haemorrhage and also the $B$ vitamins as patients receiving continuous intravenous glucose may otherwise develop a conditioned $B$ complex deficiency.

In those patients who are noisy or excited in the stage of impending coma sedation presents a most difficult problem. The long acting barbiturates are handled largely by the kidneys and are therefore the drugs of choice, but Sessions, et al. (1955), have recently published evidence to show that even the quick acting barbiturates are handled better by patients with liver disease than was previously thought to be the case.

In summary it may be said that careful attention to the fluid and electrolyte balance and an adequate supply of calories, preferably as intravenous glucose, are the corner stones on which the therapy of hepatic coma must be based. Of the various forms of treatment aimed directly at correcting the biochemical lesion causing coma, severe restriction or complete withdrawal of dietary protein and the use of glutamate are best in the coma of chronic hepatic disease, while cortisone should be tried in large doses in acute hepatic necrosis. In the latter condition, however, no therapy can hope to achieve a high cure rate until an antibiotic active against the hepatitis virus becomes available.

\section{BIBLIOGRAPHY}

ADAMS, R. D., and FOLEY, J. M. (r953), 'Metabolic and Toxic Diseases of the Nervous System,' Vol. XXXII, The Williams \& Wilkins Co., Baltimore, U.S.A.

AJMONE-MARSAN, C., FUORTES, M. G. F., and MAROSSERO, F. (1949), E.E.G. Clin. Neurophysiol.,' i, 29 I. ALSTED, G. (1947), Amer. F. Med. Sci., 213, 257.

ARTMAN, E. L., and WISE, R. A. (1953), Amer. F. Med., 15, 459. BENITEZ, D., PSCHEIDT, G. R., and STONE, W. E. (1954), Amer. F. Physiol., 176, 488.

Continued overleaf. 
BESSMAN, S. P. (1956), 'Inorganic Nitrogen Metabolism,' edited by McElroy, W. D., and Glass, B., The Johns Hopkins Press, Baltimore.

BESSMAN, S. P., and BESSMAN, A. N. (1955), f. clin. Invest., 34, 622 .

BESSMAN, S. P., and BRADLY, J. E. (1955), New Engl. F. Med., 253, 1143 .

CARAFAGANO, S. C., DE HORATIUS, R. F., THOMPSON, C. M., and SCHWARTZ, H. P. (1953), Ibid., 249, 303.

CHALLENGER, F., and WALSHE, J. M. (1955a), Lancet, i, 1237.

CHALLENGER, F., and WALSHE, J. M. (1955b), Biochem. $\mathcal{F}$., $59,372$.

DUCCI, H., and KATZ, R. (1952), Gastroenterol., 21, 357.

EDSON, N. L. (1935), Biochem. F., 29, 2082.

EISENMENGER, W. J., SLATER, R. J., and BONGIOVANNI, A. M. (1952), Amer. F. Med., 13, 27.

EVANS, A. S., SPRINZ, H., and NELSON, R. S. (1953), Ann. Int. Med., 38, 1148 .

FARQUHAR, J. D., STOKES, J. Jr., WHITLOCK, C. M. BLUEMÉLE, L. W., and GAMBIESCA, J. (1950), Amer. $\mathscr{\mathfrak { y }}$. Med. Sci., 220, 166.

FINDLAY, M., MAGEE, W. L., and ROSSITA, R. J. (1954), Biochem. F., 58, 236.

GABUZDA, G. J. Jr., PHILLIPS, G. B., and DAVIDSON, C. S. (1952), New Engl. F. Med., 246, 124.

GORE, M. B. R., and McILWAIN, H. (1952), 7. Physiol., $117,471$.

HALE, W. W., and KING, R. P. (1955), Proc. Soc. Exper. Biol. and Med., 89, 112.

HEAD, M. J., and ROOK, J. A. F. (1955), Nature, Lond., 176, 262.

HILTON, J. G. (1952), Amer. F. Med., 12, 311.

LEPPER, M. H., WOLFE, C. K., ZIMMERMAN, $H_{\text {. }} \mathrm{J}$., CALDWELL, E. R., SPIES, $H$. W., and DOWLING, $\dot{H}$. $F$ (1951), Arch. Int. Med., 88, 271 .

LISAN, P., GAMBIESCA, J. M., THOMPSON, C. M., and FUCHS, M., paper read before the American Ássociation for the Study of Liver Disease, abstract in Lancet (1955), ii, 1322

MANN, P. J. G., TENNENBAUM, M., and QUASTEL, J. H. (1939), Biochem. F., 33, 822.

MARRAZZI, A. S., and ROSS HART, E. (1955), Science, 121, 365.

MCDERMOTT, W. V. Jr., and ADAMS, R. D. (1954), f. clin. Invest., 33, $\mathrm{I}$.

McILWAIN, H. (1953), f. Neurol. Neurosurg. \& Psychiat., 16, 257

PATEK, A. J. Jr. (1954), Bull. N.Y. Acad. of Med., 30, 43.

PHEAR, E. A., SHERLOCK, S. V. P., and SUMMERSKILL, W. H. J. (1955), Lancet, i, 836 .

PHEAR, E. A., RUEBNER, B., SHERLOCK, S. V. P., and SUMMERŚKILL, W. H. J.'(1956), Clin. Sci., 15, 93 .
PHILLIPS, G. B., SCHWARTZ, R., GABUZDA, G. J. Jr., afि DAVIDSON, C. S. (1952), New Engl. F. Med., 247, 239. POLAK, A. (1956), Lancet, i, 484.

POST, J., ROSE, J. V., and SHORE, S. M. (1951), Arch. Int. Me 87,775 .

REID, R. J. (1950), Aust. F. Agricult. Research, I, 182.

REPP, W. W., HALE, W. H., CHENG, E. W., and BURROUGHS W. (1955), F. Animal Sci., 14, 118. RICHTER, D., and DAWSON, R. M. C. (1948), f. Biol. Chents
I76, I I99.

RIDDELL, A. G., and MCDERMOTT, W. V. Jr. (1954), Lancet, 1263.

RIDDELL, A. G., KOPPLE, P. N., and MĊDERMOTT, W. 穴 Jr. (1954), Surgery, 36, 675. RUTENBERG, A. M., and PINKES, S. (1952), New Engl. F. Medo
247, 797.

SCHWARTZ, R., PHILLIPS, G. B., GABUZDA, G. J. Jr, and DAVIDSON, C. S. (1953), Ұ. Lab. clin. Med., 42,499 .,

SESSIONS, J. T. Jr., MINKEL, H. P., BULLARD, J. C., and" INGELFINGER, F. J. (1954), $\mathcal{F}$. clin. Invest., 33, I 116.

SHANK, R. E. (1952), Amer. F. Med., 12, 486.

SHERLOCK, S. V. P., SUMMERSKILL, W. H. J., WHIT L. P., and PHEAR, E. A. (1954), Lancet, ii, 453.

SKLAR, M., and YOUNG, I. I. (1955), Amer. f. Med. Sch. 229, 138 .

STERN, J. M., EGGLESTON, L. V., HEMS, R., and KREBS, H. A. (1949), Biochem. Э., 44, 410 .

VAN CAULAERT, E., DEVILLER, C., and HALFF, M. (I933) Presse Medicale, II, 217.

WALSHE, J. M. (1951), Quart. F. Med. N.S., 20, 421.

WALSHE, J. M. (1953), Ibid., 22, 483.

WALSHE, J. M. (1953), Lancet, i, 1075.

WALSHE, J. M. (1955), Ibid., i, 1235.

WALSHE, J. M. (1956), In preparation.

WATSON, C. J. (1949), Ann. intern. Med., 31, 405.

WEBSTER, L. T. Jr., and DAVIDSON, C. S. (1956), f. clip Invest., 35, I91.

WEIL MALHERBE, H. (1950), Physiol. Rev., 30, 549.

WEIL MALHERBE, H. (1952), Biochem. Soc. Symposia, No. $8 \Omega_{1} \overrightarrow{0}$ WEIL MALHERBE, H. (1955), Biochem. f., 61, 210.

WHITE, L. P. PHAER, A SUMMERSKILL W SHERLOCK, S. V. P., and COLE, M. (I955), Ibid WILSON, T. G., and MCALPINE, D. (1953), Proc. Roy. Soc Med., 46, Nos. 3, 12.

\section{OBSTETRICS \& GYNAECOLOGY}

(Postgraduate Medical Journal, July, 1954)

Price : 3s. 10d., post free

\section{INTRODUCTORY}

Charles D. Read, F.R.C.S., F.R.C.O.G.

\section{RESPIRATORY HAZARDS IN THE} PREMATURE INFANT

Albert E. Claireaux, M.D., M.R.C.P.

POSTMATURITY

S. G. Clayton, M.D., M.S., F.R.C.O.G.

THE RELATIVE MERITS OF THE VARIOUS BIOLOGICAL TESTS FOR PREGNANCY

H. P. Ferreira, M.D.

\section{PELVIC THROMBOSIS}

J. Stallworthy, F.R.C.S., F.R.C.O.G.

THE EARLY DIAGNOSIS OF GENITAL CANCER BY CYTOLOGY

Erica Waechtel, M.D.

THE MENOPAUSE

G. I. M. Swyer, D.M., M.R.C.P.

THE PLACE OF ULTRA-RADICAL SURGERY IN ADVANCED MALIGNANT DISEASE IN THE PELVIS

J. B. Blaikley, F.R.C.S., F.R.C.O.G.

Published by

THE FELLOWSHIP OF POSTGRADUATE MEDICINE

60, Portland Place, London, W.1 